\title{
ŹRÓDŁA WARSZAWSKIEGO SMOGU I KIERUNKI NAPRAWY TEJ SYTUACJI W MIEJSCU JEJ PRZYCZYN
}

\author{
Krystyna Guranowska-Gruszecka ${ }^{\circledR}$ \\ Wydział Architektury, Politechnika Warszawska
}

\begin{abstract}
STRESZCZENIE
Celem artykułu jest przedstawienie źródeł smogu w mieście stołecznym Warszawie na podstawie przeglądu dostępnych badań instytucji sanitarnych z ostatnich lat i autorskich obserwacji zachodzących zjawisk. Przyjęto hipotezę badawczą, że oprócz chemicznych zanieczyszczeń z powietrza na tworzenie się smogu miejskiego istotny wpływ ma też kształtowanie urbanistyki miasta, w tym planowanie układu zabudowy względem systemu zieleni miejskiej, zmotoryzowanego transportu zbiorowego i indywidualnego, infrastruktury technicznej w budynkach oraz stosowanie zasad zarządzania w działaniach inwestycyjnych na większą skalę, co w Polsce jest pomijane. Oprócz analizy współczesnych materiałów źródłowych dotyczących smogu jako nienaturalnego zjawiska wspólistnienia w atmosferze toksycznych związków chemicznych i pyłów przedstawiono kierunki naprawy tej sytuacji. Powołano się na rozwiązania z innych miast europejskich (np. Gandawa czy Oslo) i porównano je z sytuacją w Warszawie. Zastosowano zatem metody porównawcze z wzorcowymi przykładami (metoda case study), prezentując przykłady zakończone sukcesem udanej ochrony środowiska miejskiego. W części wnioskowej podkreślono wielonurtowe kierunki działań naprawczych, także konieczność stosowania zasad zarządzania w działaniach ochronnych środowiska Warszawy - ważnych dla realizacji założonych celów, a nie stosowanych.
\end{abstract}

Słowa kluczowe: smog, zmiany klimatyczne, paleniska domowe, promieniowanie radiofalowe 5G, ściany i chodniki chłonące zanieczyszczenia, dążenie do bezemisyjności, zasady sieci transportowej w śródmieściu

\section{WSTĘP}

Narastająca w Warszawie sytuacja pogarszania się jesienią stanu powietrza, zwłaszcza na obszarze stołecznego śródmieścia, w postaci żółtawej, a czasem fioletowej czy niebieskiej chmury mgły otulającej zabudowę - prowokuje do dogłębnego omówienia tego tematu. Stan takiego zanieczyszczenia trwa przez zimę aż do wiosny. Użytkownicy tych obszarów jeszcze przed pandemią coraz częściej zaczynali używać ochronnych opasek zasłaniających dolną część twarzy, tj. nozdrza i usta. Cztery lata temu pojęcie smogu uważano za „temat niszowy”, jednak pogarszający się stan powietrza w ostatnich latach temu zaprzecza. Smog wcześniej kojarzony z miasteczkami Polski Południowej położonymi u stóp gór lub z miastami przemysłowego Śląska, wobec zwiększającej się tzw. niskiej emisji pochodnej spalania śmieci, ale i węgla niskiej jakości, obecnie dotyczy wielu zurbanizowanych ośrodków, w szczególności metropolitalnych. W artykule omówiono nienaturalne zjawiska atmosferyczne polegające na wspólistnieniu związków chemicznych oraz pyłów w atmosferze i innych jej składników szkodliwych dla zdrowia. 
W Warszawie, mieście o rosnącej liczbie pracowników, zagrożenie zdrowia skutkami smogu sukcesywnie wzrasta.

Problemem badawczym jest wzrastające zagrożenie zdrowia skutkami smogu w Warszawie, mieście o wzrastającej liczbie pracowników. Zwłaszcza w rejonie centrum stołecznej metropolii powiększa się liczba miejsc pracy, które oferują przedsiębiorstwa $\mathrm{z}$ całej Polski, Europy, także $\mathrm{z}$ innych kontynentów (np. z Ameryki Północnej) oraz kulturowe, biznesowe czy komercyjne instytucje ${ }^{1}$. Wszystkie tereny pełniące wcześniej funkcje magazynowe lub produkcyjne począwszy od 1989 roku zamieniono na nowe zespoły biurowe (Służewiec Przemysłowy, rejon zachodni Al. Jerozolimskich aż po zachodnią granicę miasta, Wola - zachodnia część śródmieścia), także tereny pokolejowe w rejonie Dworca Gdańskiego i tereny poportowe na Pradze Północ. Walka developera o program mieszkaniowy na dawnych portowych pirsach nadal trwa, chociaż ten krajobrazowo atrakcyjny teren powinien być zagospodarowany jako przestrzennie publiczne dostępne dla wszystkich. Trzy opasłe drapacze chmur w rejonie ronda Daszyńskiego wznoszone tuż przed pandemią mają powierzchnię biur większą niż wszystkie biura w Łodzi. Pracownikom biurowców trudno tam dojechać komunikacją publiczną, próbowali samochodami, stawiając je wśród zabudowy mieszkaniowej nowych osiedli wokół ${ }^{2}$. Te nowe zespoły miejsc pracy powstają bez stosownych profesjonalnych obliczeń, wykorzystując maksymalnie pojedyncze działki, dla których w związku z tym, że nie są objęte ustaleniami planu miejscowego, wydano jedynie odpowiednią decyzję o warunkach zabudowy - prawo stosowane tylko w Polsce.

Głównym tematem opracowania są kierunki działań naprawczych klimatu w mieście stołecznym na podstawie wyników badań profesjonalnych służb miejskich, według właściwych zasad projektowania i planowania przestrzennego oraz dzięki konsekwen- tnej realizacji założeń. Podjęta także będzie dyskusja, czym powinien być „rozwój zrównoważony” - podstawowa idea współczesnej urbanistyki miejskiej.

Procesom tym służy też porównanie $\mathrm{z}$ innymi bardziej zaawansowanymi miastami Europy jak wzorcowe przykłady Gandawy i Oslo, które przez wiele lat tworzyły swoje nowe oblicza - miast dla pieszych o ograniczonym ruchu samochodowym w śródmieściu, czy Londynu, gdzie na miejsce portu, którego świetność zakończyła się wraz ze schyłkiem kolonialnej potęgi Imperium Bytyjskiego, stworzono nowoczesne centrum.

W przypadku Warszawy do najbardziej wartościowych opracowań dotyczących tego zagadnienia należy Atlas ekofizjograficzny m.st. Warszawy (Biuro Architektury i Planowania Przestrzennego Urzędu m.st Warszawy [BAiPP], 2018), który stanowi materiał wstępny do nowego studium uwarunkowań i kierunków zagospodarowania przestrzennego miasta. Zawarto $\mathrm{w}$ nim uwarunkowania przyrodnicze, ale też rekomendacje właściwego kierunku przekształceń przestrzeni w obrębie gminy Warszawa. Po raz pierwszy w udostepnianym publicznie urzędowym dokumencie znalazły się wzorce tarasów i innych rozwiązań z udziałem powierzchni zieleni oraz dachów i ścian z dostosowana do takich warunków roślinnością w przypadkach zbyt małych powierzchni biologicznie czynnych na planowanych terenach zabudowy (przykłady tych wzorców na rys. 1).

Istnieje także bogata literatura dotycząca gospodarki odpadami w skali aglomeracji oraz wyników kontrolnych zakresu stosowania się gmin ościennych do obowiązujących przepisów sanitarnych w zakresie gospodarki wodnej i ściekowej ${ }^{3}$. Bogato przedstawia się także literatura dotycząca spalanych $\mathrm{w}$ piecach materiałów, które bardzo często są odpadami, a nie paliwami specjalnie do tego przeznaczonymi. $\mathrm{W}$ porównaniu z innymi polskimi ośrodkami zurbanizowanymi Warszawa z opóźnieniem zaczęła walkę

\footnotetext{
${ }^{1}$ Znakomicie działający w Polsce rynek handlu nieruchomościami po 1989 roku, zawłaszczony na początku XXI wieku przez konkurujących biznesmenów amerykańskich, całkowicie przez nich został przejęty wraz ze stowarzyszeniami zawodowymi, które przyjęły nowe zasady ( $\mathrm{z}$ doświadczeń autorki, lata 90.).

${ }^{2}$ Informacje uzyskane podczas wykładu i z prezentacji firmy JEMS Architekci (2019), z której wywodzą się autorzy osiedla mieszkaniowego 19. Dzielnica powstałego w sąsiedztwie ronda Daszyńskiego.

${ }^{3}$ Stowarzyszenie Program Czysta Polska (https://www.programczystapolska.pl, dostęp 13.12.2020).
} 

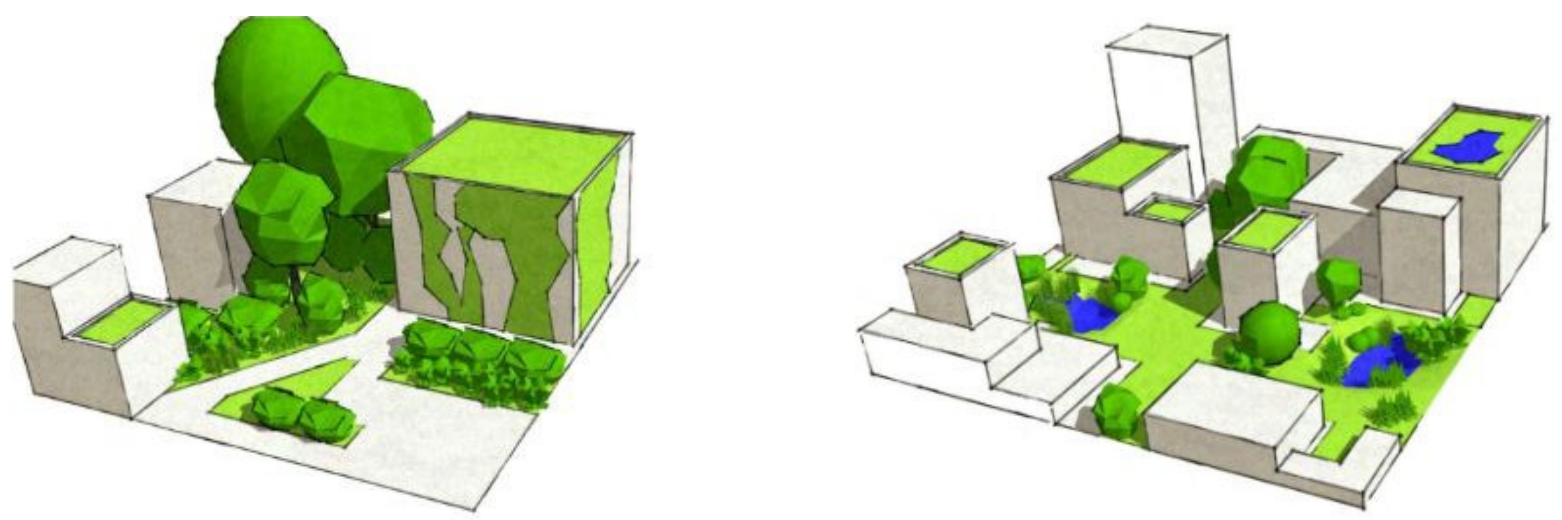

Rys. 1. Ilustracje zaleceń kształtowania zabudowy z udziałem różnych form zieleni (BAiPP, 2018)

Fig. 1. Illustrations of recommendations for shaping development with the participation of various forms of greenery (BAiPP, 2018)

z zanieczyszczeniem powietrza (Airly, 2020). Dla stolicy nie powstały żadne kompleksowe opracowania badawcze dotyczące problemów związanych z pogarszającą się jakością warszawskiego powietrza, ale istnieją inicjatywy pozarządowe, np. stowarzyszenie Miasto Jest Nasze opracowało dla m.st. Warszawy „mapę” 1,9 tys. lokali ogrzewanych najtańszym paliwem (węglem). Dotyczy to zabudowy po prawej stronie Wisły (Praga Północ, Praga Południe) oraz miejscowości położonych w kierunku południowo-zachodnim od centrum wzdłuż linii kolejowej (Pruszków i inne). Na skutek dominujących kierunków wiatrów z zachodu i południowego zachodu, gdzie najbardziej rozwinięte są tereny zabudowy jednorodzinnej, a domy/lokale ogrzewane sa wcześniej opisanymi metodami, zanieczyszczenia docieraja do centrum miasta. W dyskusji także poruszono pierwsze reakcje stołecznych władz miejskich w kierunku odzysku surowców i energii z odpadów ${ }^{4}$ - działania wspierane przez społeczności lokalne.

W artykule omówiono dwa rodzaje zanieczyszczeń o różnych średnicach cząstek: $\mathrm{PM}_{2,5} \mu \mathrm{m}$ (zawiera cząstki o średnicy mniejszej niż 2,5 $\mu \mathrm{m}$ ) oraz $\mathrm{PKM}_{10}$ (zawiera cząstki o średnicy mniejszej niż $10 \mu \mathrm{m}$ ). Mniejsze cząsteczki bez przeszkód są wchłaniane do organizmu ludzkiego przy oddychaniu i potem dostają się do układu krwionośnego. Większe wchłaniane są do pluc ${ }^{5}$ (European Environment Agency [EEA], 2020).

W pracy poruszono również czekający nas w najbliższej przyszłości problem tzw. piątej generacji telefonii komórkowej, której globalne wdrożenie negatywnie wpłynie na stan zdrowia ludzi na Ziemi (Firstenberg, 2019). W artykule podjęto próbe wskazania działań naprawczych tych niekorzystnych zjawisk towarzyszacych postepowi technologicznemu w tym kierunku, np. stosowania ochronnych polaryzatorów torsyjnych. Przedstawiono także przykład wzorcowej przebudowy centralnej części miasta Gandawy, która miała na celu całkowite zastapienie transportem publicznym męczacego i szkodliwego dla zdrowia ruchu samochodów osobowych (Prokop i Pawlak, 2018). Działania takie są prowadzone w wielu miastach Europy Zachodniej. W Polsce ciągle czekamy na uruchomienie tego kierunku poprawy warunków poruszania się po mieście (Prokop i Pawlak, 2018).

\footnotetext{
${ }^{4}$ Eko Impuls dla Warszawy - projekt rozbudowy i modernizacji Zakładu Unieszkodliwiania Stałych Odpadów Komunalnych zlokalizowanego na warszawskim Targówku w celu m.in. wdrożenia nowoczesnej instalacji do odzysku surowców i energii z odpadów (https://www.eko-impuls.pl/o-projekcie, dostęp 30.11.2020).

${ }^{5}$ Zasady te potwierdzają liczne opracowania naukowe, zwłaszcza literatura światowa już od lat 70. XX wieku obfitująca w wyniki badań w tym zakresie (MacGregor, Casciano i Müller, 2000; Bhattacharyya, Klerks i Nyman, 2003; Traczewska, 2011).
} 


\section{SMOG I OGÓLNE PRZYCZYNY JEGO POWSTAWANIA}

\section{Definicje}

W opracowaniach naukowych spotykamy różne definicje smogu. Dla celów tego artykułu obejmującego wielowarstwowe aspekty przyczyn niedogodności klimatycznych w metropolii stołecznej, także w związku ze sposobem kształtowania funkcjonalno-przestrzennego miasta, założono następującą definicję. Smogiem określono nienaturalne zjawisko atmosferyczne (od ang. smoke i fog) polegające na współistnieniu związków chemicznych oraz pyłów w atmosferze. Smog jest sztuczną mgłą powstałą w nienaturalny sposób na skutek działań ludzkich oraz niesprzyjających zjawisk przyrody (Airly, 2019). Istnieje wiele innych podobnych definicji.

Dostawszy się przy oddychaniu do organizmu ludzkiego smog zagraża zdrowiu i życiu. Obecnie $30 \%$ dzieci w przedszkolach ma dolegliwości związane $\mathrm{z}$ oddychaniem.

Wyróżniane dwa typy smogu: powstający głównie w letnich miesiącach $\mathrm{w}$ strefach tropikalnych (typ Los Angeles) oraz występujący zwykle od listopada do wiosny w umiarkowanej strefy klimatycznej (typ londyński).

Smog stanowi mieszankę powietrza z zanieczyszczeniami i ze spalinami powstającymi w wyniki działalności ludzkiej. Przyczyną są emisje z fabryk, samochodów, palenie w piecach węglem, drewnem i innymi paliwami stałymi. Ponadto przyczynia się do tego także pogoda, klimat, kierunki i wzrastająca ostatnio prędkość wiatrów. Do rozrzedzenia zanieczyszczeń w powietrzu trudniej jest doprowadzić na terenach zurbanizowanych położonych w kotlinach np. wzdłuż gór, łatwiej na terenach płaskich. W Warszawie źródłem emisji tak częstego $\mathrm{w}$ ostatnich latach smogu nad śródmieściem jest rozwinięte osadnictwo na zachodzie metropolii, gdzie w prawie każdym domu jednorodzinnym występuje ogrzewanie piecowe na węgiel i drewno; czasem odbywa się też palenie w kominkach śmieci. Wiatry o dominującym kierunku $\mathrm{z}$ tamtych rejonów przeno- szą zanieczyszczone powietrze nad centrum miasta, pogarszając panujące tam warunki atmosferyczne. W Słowniku wspótczesnego języka polskiego z 2001 roku smogiem określane jest zjawisko występujące na terenach przemysłowych (Dunaj, 2001). Okazuje się, że w niecałe 20 lat później po opublikowaniu tej informacji rozwój miast i sieci transportowej wraz ze środkami poruszania się po kraju i miastach przyniósł nowe zagrożenia na wielu terenach miejskich, często niemających z przemysłem nic wspólnego. Dwa lata temu Agnieszka Starzyk w swoim rozdziale do książki Węzly miasta, zatytułowanym Sensualna percepcja miejskości zaprezentowała szokujące zdjęcia ze śródmieścia Warszawy spowitego w żółtoszarej mgle, intuicyjnie przewidując zmianę wizerunku tego miasta, co obecnie już nastąpiło (Starzyk, 2018).

Rozwiązanie tego problemu wymaga szybkiej riposty w postaci programów naprawczych opartych na zrozumieniu przyczyn negatywnych zjawisk. Obecnie oprócz zdrowotnych uciążliwości dla ludzi (obniżenie odporności organizmu, niewydolność oddechowa, choroby układu krwionośnego i serca, skłonność do chorób nowotworowych) skażeniu ulega także mięso zwierząt oraz tkanki roślin wzrastających w takich warunkach, także materiały budowlane, do których dostają się agresywne czynniki chemiczne. Podobnie skażone mogą być produkty mające kontakt z żywnością takie jak opakowania czy tekturowe talerze i kubki na gorące posiłki ${ }^{6}$. Konieczne są zatem kompleksowe działania oczyszczenia powietrza $\mathrm{z}$ tych negatywnych zjawisk, dotyczące wszystkich sfer opisanych w tym artykule.

\section{Rodzaje zanieczyszczeń}

Zanieczyszczenia dzielą się pod względem stopnia zagrożenia zdrowia ludzkiego na dwa typy różniące się średnicą cząsteczek, przekładającą się na aerodynamiczną średnicę cząstek. Ze źródeł takich jak paleniska domowe i transport drogowy do powietrza dostają się cząsteczki o bardzo małej wielkości $\mathrm{PM}_{2,5}$ (do 2,5 $\mu \mathrm{m}$ średnicy). Biorąc pod uwagę tę średnicę, cztery razy mniejszą od przeciętnej średnicy włosa, bez problemów dostają się do układu oddechowego

\footnotetext{
${ }^{6}$ Komunikaty dotyczące wycofanych z rynku wyrobów do kontaktu z żywnością publikowane są na bieżąco na witrynie internetowej Głównego Inspektoratu Sanitarnego w dziale Ostrzė̇enie publiczne dotyczące żywności (https://www.gov. pl/web/gis/ostrzezenia).
} 
przy oddychaniu, a następnie przenikają do układu krwionośnego, zatruwając go. Nieco większe cząstki $\mathrm{PKM}_{10}$ o średnicy do $10 \mu \mathrm{m}$ to wynik emisji ze spalania paliw stałych (węgiel, drewno oraz biomasa) w systemach grzewczych różnorodnych budynków oraz zanieczyszczeń emitowanych przez pojazdy w ruchu drogowym. Największe zanieczyszczenia pochodzą z pojazdów z silnikami wysokoprężnymi bez filtrów wyłapujących cząstki stałe (Motofaktor.pl, 2020).

Uwarunkowania klimatyczne smogu to mgła, bezwietrzna pogoda i duża wilgotność. Najbardziej trującymi substancjami w smogu są: tlenki siarki i azotu, ozon oraz węglowodory aromatyczne, w tym najbardziej z nich szkodliwym jest benzo(a)piren.

Za okresowe występowanie smogu w Polsce na terenach zurbanizowanych odpowiada tzw. niska emisja powstająca na skutek ogrzewania mieszkań przez piece oraz ze spalin samochodowych. Średnia procentowa podawana przez Najwyższą Izbę Kontroli sprzed dwóch lat wskazuje, że 82-92,8\% zanieczyszczeń pochodzi z niskiej emisji, zaledwie $5,4-7 \%$ to zanieczyszczenia komunikacyjne, a $1-9 \%$ to przemysłowe. Ten problem NIK zgłaszała już w 2000 roku, w 2016 opracowała obszerny raport pokontrolny dotyczacy województwa śląskiego, a w 2020 na jej witrynie internetowej pojawił się komunikat oraz artykuł w tej sprawie (Najwyższa Izba Kontroli [NIK], 2000, 2016, 2020). Uśrednienie w skali większych obszarów nie daje jednak prawdziwego obrazu ${ }^{7}$. Zwłaszcza Warszawa odbiega znacznie od tej statystyki, przyciągając jak magnez mieszkańców i pracowników, biznes, aktywność i zróżnicowane zachowania społeczne. W stolicy w 2011 roku emisja liniowa (na ciągach komunikacyjnych) odpowiadała za $63 \%$ stężenia zanieczyszczeń $\mathrm{PM}_{10}{ }^{8}$.

\section{Dominujące źródła smogu w śródmieściu Warszawy}

Dążąc do odpowiedzi na pytanie o prawdziwe źródła smogu w miejscu jego powstawania, interesująco przedstawiają się badania uzyskane w 2019 roku dla województwa mazowieckiego, prezentowane przez Katarzynę Barańską z Wojewódzkiego Inspektoratu Ochrony Środowiska, w 2020 roku traktowane na forum publicznym jako dorobek WIOŚ. Zanieczyszczenia będące wyziewami $\mathrm{z}$ rur samochodowych, o co powszechnie oskarża się te elementy środków lokomocji - to zaledwie 7\%, „kilkanaście procent to drobinki z opon samochodowych i klocków hamulcowych. Pozostałe czyli ok. 80\% [zanieczyszczeń samochodowych] to pylenie wtórne, czyli to, co leży na jezdni, a samochody wzbijają w powietrze przejeżdżając”. Niestety nazwisko p. Barańskiej „wykasowano z Internetu", traktując to jako dorobek WIOŚ (Wojewódzki Inspektorat Ochrony Środowiska w Warszawie [WIOŚ], (2019). Takie wyniki badań z 2017 roku przedstawiała Barańska w 2018 roku dla Warszawy.

Nasuwa się zatem pytanie, w jaki sposób najlepiej ochronić śródmieście obszaru metropolitalnego Warszawy od tych zanieczyszczeń? Jeżeli przestana po tych wyselekcjonowanych terenach jeździć samochody, to jest szansa, aby zniknęło $80 \%$ zanieczyszczeń przez nie powodowanych. Do takich wniosków doszły już władze samorządowe wielu dużych europejskich miast, w których począwszy od ostatniej ćwierci $\mathrm{XX}$ wieku wyznacza się i organizuje wybrane strefy miejskie przeznaczone wyłącznie dla ruchu pieszego i rowerowego. Około pięć lat temu, przed ówczesnymi wyborami do samorządu m.st. Warszawy, partycypanci tego procesu proponowali takie rozwiązanie w stołecznym śródmieściu. Akceptacja tego pomysłu trwała aż do wyborów samorządowych, po czym oburzeni politycy skrytykowali brak możliwości dla nich samych dojazdu do obiektów administracji publicznej położonych w centrum, chociaż nikt nie kwestionował dopuszczenia ruchu samochodów uprzywilejowanych.

Rozwiązanie tego problemu nadal zależy od organizacji transportu zbiorowego w centrum miasta. Jeżeli nie będzie rozwiązany zgodnie ze współczesnymi zasadami teoretycznymi kształtowania tych zagadnień w cywilizowanych miastach Europy Zachodniej, to

\footnotetext{
${ }^{7}$ Witryna internetowa Wojewódzkiego Inspektoratu Ochrony Środowiska w Krakowie (krakow.pios.gov.pl, dostęp 10.09.2020); witryna internetowa Wojewódzkiego Inspektoratu Ochrony Środowiska w Warszawie (www.wios.warszawa. pl, dostęp 10.09.2020).

${ }^{8}$ Witryna internetowa Głównego Inspektoratu Ochrony Środowiska zamieszczająca dane pomiarowe zanieczyszczeń powietrza w Polsce (https://powietrze.gios.gov.pl, dostęp 19.10.2020).
} 
oczywiście sprawność obsługi transportem publicznym strefy śródmiejskiej stanowić będzie barierę nie do pokonania. W ciągu ostatnich kilku lat powstała spora literatura na te tematy - zarówno monografie (Pecenik, 2017), jak i artykuły w naukowych periodykach pisane główne przez pracowników Wydziału Architektury Politechniki Warszawskiej. Nawet studenci kursów magisterskich tego wydziału jeżdżący na stypendia po Europie przywożą i publikują materiały dotyczące rozwiązań uwolnienia stref centralnych miast od ruchu samochodów (Prokop i Pawlak, 2018). Szkoda, że środowisko inżynierów specjalizujących się $\mathrm{w}$ transporcie zbiorowym $\mathrm{w}$ miastach nie rozważa tego tematu w skali urbanistycznych zasad, które muszą być przestrzegane, aby w odpowiedzialny sposób ukształtować system tej komunikacji w mieście.

W związku z tym przedstawiono przynajmniej wybrane ogólne zasady stanowiące współczesne standardy postępowania w śródmieściach miast europejskich. Należy do tego dodać, że Polska podpisując Europejską Karte Planowania Przestrzennego, zobowiązała się do jej przestrzegania. Już na konferencji pt. Gospodarka przestrzenna, stan obecny $i$ wyzwania przyszłości - ujęcie interdyscyplinarne, która odbyła sie we Wrocławiu w 2017 roku, zwrócono uwagę na brak spójności polskich i europejskich zasad planowania przestrzennego. Należy w końcu dołączyć do Europy i zacząć przestrzegać te zasady, a nie powielać te mające swoje źródło w uwarunkowaniach gospodarki centralnie panowanej, które od dawna są już przestarzałe.

Istotnym elementem wpływającym pozytywnie na stan powietrza $\mathrm{w}$ centrum metropolii są właściwie zlokalizowane i racjonalnie rozmieszczone węzły przesiadkowe między różnymi środkami transportu. Świadczą o tym ostatnio publikowane mapy Europy ilustrujące poziom zanieczyszczeń, gdzie na terenie Polski zaznaczone są największe wartości. Kraje Europy Zachodniej już w znacznym stopniu poradziły sobie $\mathrm{z}$ tymi problemami.

W standardach europejskich założono zagospodarowanie śródmieść miejskich z myślą o wygodzie mieszkańców i użytkowników tych obszarów oraz w dążeniu do sprawnej likwidacji uciążliwości, a nie utrzymywania status quo. Czas aby zauważyć, że świat zmienia się i rzutuje to także na zmiany kształtowania śródmieść. Nie chodzi wszak o blokowanie terenów śródmiejskich, ale o ich rozwój. Jeżeli zmienia się liczba nowych obiektów generujących codzienną aktywność, to muszą zmieniać się inne elementy zagospodarowania, w tym powinna poprawiać się dostępność tej nowej zabudowy i nowych funkcji, co jest podstawowym warunkiem zrównoważonego rozwoju.

Ponad 40 lat temu Christopher Alexander opisał problemy związane $\mathrm{z}$ projektowaniem miejskiego transportu. Źle zorganizowane węzły przesiadkowe przyczyniają się do klęski transportu zbiorowego, gdyż mają pierwszorzędną pozycję i od ich racjonalnego rozmieszczenia należy rozpoczać projektowanie układu transportu publicznego w mieście. Linie transportowe są drugorzędnym elementem sieci; powinny one łączyć węzły przesiadkowe (Alexander, 2008). Tymczasem w Warszawie poszczególni przewoźnicy projektują jedynie linie reprezentowanych środków transportu, co skutkuje brakiem koordynacji węzłów przesiadkowych ${ }^{9}$.

W krajach Europy Zachodniej kiedy dojeżdża się z peryferii metropolii do granic śródmieścia lub jego części wyłączanej ze zmotoryzowanego transportu indywidualnego, napotyka się pierwszy węzeł. Samochody pozostają $\mathrm{w}$ wielopoziomowych garażach na granicy strefy obsługiwanej głównie przez transport zbiorowy. Należy przesiąść się w metro, tramwaj, autobus (oczywiście z napędem elektrycznym, trolejbus, mniejsze busy z napędem elektrycznym). Tramwaje mogą oczywiście $\mathrm{w}$ granicach dzielnic historycznych mieć napęd ładowany od dołu, z poziomu jezdni między szynami, żeby nie ingerować siecią elektryczną w krajobraz zabytkowej ulicy.

W zakresie optymalnych dystansów między różnymi środkami transportu publicznego zalecono zachowanie następujących zasad: przejście $\mathrm{z}$ jednego peronu przystankowego do drugiego nie powinno zająć więcej niż 3 min (długość 180-200 m), 30 m przy przesiadce $\mathrm{z}$ autobusu na tramwaj lub na odwrót, $60 \mathrm{~m}$

\footnotetext{
${ }_{9}^{9}$ Publikowane powszechnie na początku bieżącego roku 2020 wyniki ankietyzacji przeprowadzonej przez Urząd m.st. Warszawy wśród użytkowników transportu zbiorowego w stolicy ujawniły, że ponad 8 tys. węzłów przesiadkowych w mieście jest zaprojektowanych z licznymi utrudnieniami komplikującymi podróż środkami transportu publicznego.
} 
$\mathrm{z}$ metra do autobusu lub tramwaju, $90 \mathrm{~m} \mathrm{z}$ pociągu podmiejskiego do metra (Alexander, 2008).

Sformułowano też wytyczne projektowe, żeby instalować podcienia i wiaty, co zwłaszcza w obecnych uwarunkowaniach klimatycznych zarówno w ciepłych porach roku, jak i zimą stanowi ochronę dla oczekujących na przystankach. Połączeń między peronami nie należy krzyżować z ulicami (Alexander, 2008).

Już ponad 40 lat temu w miastach Europy Zachodniej w węzłach przesiadkowych zalecono tworzenie miniaturowych centr życia publicznego o rozpoznawalnej formie, przyjemnych dla oczekujących, wygodnych i bezpiecznych. Sugerowano również ewentualne oddanie tych miejsc w zarządzanie lokalnym społecznościom (Alexander, 2008). Jako główne wytyczne do projektowania takich miejsc wskazano: skracanie czasu przesiadki, wytyczanie prostych dróg dojścia bez schodów, różnic poziomów i ciemnych zaułków, tworzenie atrakcyjnej przestrzeni publicznej oraz koordynowanie rozkładów jazdy transportu zbiorowego (Alexander, 2008). Ten ostatni punkt jest niezwykle ważny. Kiedy wysiada się z metra czy pociąu w węźle przesiadkowym, powinna istnieć możliwość przemieszczania się dalej w ciągu paru minut (Pecenik, 2017). Warto zauważyć, że wobec braku projektów skoordynowanych węzłów przesiadkowych w Warszawie i planowania tylko linii dla każdego ze środków transportu (dla każdego oddzielnie w oddzielnej firmie) oszczędność czasu podróżujących nie jest tu zasadą. $\mathrm{Z}$ tego powodu mieszkańcy i pracownicy strefy śródmiejskiej wybierają codzienne podróże własnym samochodem dla uzyskania lepszego ich komfortu. Usprawnienie transportu publicznego zgodnie $\mathrm{z}$ przedstawionymi zasadami jest najwłaściwszą drogą do uzdrowienia śródmieścia, w tym ograniczenia smogu.

\section{Promieniowanie radiofalowe 5G}

Oprócz zróżnicowanych przyczyn warszawskiego smogu na powierzchni ziemi w najbliższych latach można spodziewać się powstania zagrożenia zdrowia związanego $\mathrm{z}$ wprowadzeniem $\mathrm{w}$ przestrzeni kosmicznej wokół ziemskiej piątej generacji telefonii komórkowej (5G). Problem ten dotyczy nie tylko Polski, ale też całego globu. Dokonujące się już zmiany w naszym środowisku życia są trudne do obiektywnej oceny, ponieważ nadal nie ma ogólnie dostępnych wiarygodnych badań o jej skutkach i wpływie na życie na Ziemi. Tym niemniej niektóre społeczności, np. Szwajcarii, Belgii i Holandii, odmówiły zgody w ogólnopaństwowym głosowaniu na wprowadzenie u siebie technologii 5G. Stąd istnieje jedynie możliwość przedstawienia dyskusji, w której prezentowane są różne poglądy i oceny wprowadzenia tej nowej technologii: pozytywne i negatywne. W 2015 roku Arthur Firstenberg zainicjował międzynarodowy apel przeciwko otoczeniu globu promieniowaniem radiofalowym, który w 2018 roku ogłoszono na witrynie internetowej $5 \mathrm{gSpaceAppeal.}$ org, za pomocą której można zgłaszać swoje uwagi i sygnować apel on-line.

Według Firstenberga (2019) wprowadzenie 5G spowoduje bezprecedensowy wzrost nieuchronnej, niedobrowolnej ekspozycji wszystkich na promieniowanie radiofalowe. Pomysł ten polega na umieszczeniu w przestrzeni kosmicznej około 20 tys. satelitów na niskich i średnich orbitach ziemskich, które otulą Ziemię skupionymi i możliwymi do sterowania wiązkami energii. Proces ten już trwa. Z satelitów będa emitowane na Ziemię fale milimetrowe (o mocy do $5 \mathrm{mln} \mathrm{W}$ ) pochodzace z tysięcy anten połączonych ze sobą w układ fazowy. Cechą tego systemu jest objęcie Internetem wszystkich zakątków Ziemi niezależnie od tego, czy będą to dalekie pustynie, obecnie niedostępne puszcze, czy morza i oceany funkcjonujące w pustce komunikacyjnej.

Dla sprawności tego systemu dodatkowym elementem będzie gęsta sieć naziemna stacji bazowych, $\mathrm{w}$ tym także Internet of Things (IoT). Miliardy zakupywanych przedmiotów od mebli do pieluszek niemowlaków będą wyposażone $\mathrm{w}$ minimalistyczne czipy umożliwiające kontakt zarządzających siecią z przedmiotami. Poza tym satelity umieszczone w magnetosferze Ziemi zmienią znacząco stan elektryki atmosfery, choć dopiero zagęszczona sieć naziemna bazowa wielokrotnie usprawni moc Internetu.

Do pozytywnych skutków tego modelu nowej technologii na pewno można zaliczyć dostępność informacji dla handlowców reprezentujących biznes przedmiotów codziennego użytku o zapotrzebowaniu wśród ludności różnych regionów na konkretne materiały, rzeczy, meble, urządzenia, ubrania, żywność 
itp. Dla uczącej się młodzieży i dorosłych żądnych informacji będzie lepszy dostęp do szeroko pojętej wiedzy o świecie. Do sfery rządzących w miastach, krajach i na różnych kontynentach dopływać będą miliony informacji o ludziach, ich przyzwyczajeniach, preferencjach, mentalności, poglądach, ale także chorobach czy ułomnościach. W środowiskach kilku instytucji już włączonych $\mathrm{w}$ program wdrażania $5 \mathrm{G}$ rozpowszechniona jest informacja, że w najbliższym czasie w Polsce w szpitalach położniczych będą przeprowadzane standardowe wszczepienia czipów niemowlętom zaraz po urodzeniu. Pokolenie to od początku będzie elementem systemu piątej generacji wraz ze wszystkimi negatywnymi skutkami. Na podstawie badań naukowych udowodniono już, że tolerowanie alteracji elektromagnetycznej Ziemi jest groźne zarówno dla zdrowia oraz życia ludzkiego, jak i dla całego środowiska przyrodniczego Ziemi i z pewnościa przyczyni się do gwałtownych jego zmian $^{10}$. Podane w cytowanym artykule skutki tego napromieniowania są imponująco złe, obejmując najgorsze schorzenia trapiące dziś, i jak się okazuje jeszcze bardziej w przyszłości - ludność globu w coraz większym stopniu ${ }^{11}$.

Zanieczyszczenie powietrza promieniowaniem radiofalowym jest niewidzialne, więc trudno nawet będzie udowodnić, jakie są przyczyny gorszego samopoczucia ludzi.

\section{KIERUNKI DZIAŁAŃ NAPRAWCZYCH KLIMATU}

Poza dopisaniem się do oficjalnej listy obywateli świata protestujących przeciwko wprowadzaniu technologii $5 \mathrm{G}$ w polskiej sferze publicznej nie ma ustalonych form dyskusji na ten temat. Rozważania o kierunkach działań naprawczych klimatu w podsumowaniu tego rozdziału z konieczności zawężone będą do problemów poddanych badaniom specjalistycznym w strefie śródmiejskiej miasta stołecznego Warszawy, w pełni dotąd rozpoznanych.

\section{Wymiana systemów grzewczych na ekologiczne}

W Polsce rozpoczęto już walkę ze smogiem w związ$\mathrm{ku} \mathrm{z}$ ustaleniem $\mathrm{w}$ toku pomiarów badawczych szkodliwości trujących dymów $\mathrm{z}$ niewłaściwych pieców grzewczych. Trwa w wielu miastach akcja dotowania na zamianę szkodliwie działających urządzeń grzewczych oraz na termomodernizację. Najnowsze wyniki tego procesu wskazują na najlepsze w kraju osiągnięcia władzy samorządowej Krakowa, gdzie mimo bardzo złych wyników jeszcze dwa lata temu sytuację w Krakowie udało się gwałtowanie poprawić.

W odróżnieniu od Krakowa w granicach metropolii warszawskiej sygnalizowane i konkretnie wskazywane przez media i lokalne społeczności lokalizacje zabudowy o najgorszych standardach grzewczych, stanowiących źródła początkowe przesuwanych potem wiatrem chmur zanieczyszczeń smogowych, $\mathrm{w}$ wielokrotnie mniejszym tempie są likwidowane.

Jak wynika z najnowszych doświadczeń krakowskich, lepsze efekty daje wydatkowanie większych sum dotacji na wymianę większej liczby pieców niż później na leczenie chorób spowodowanych smogiem, dotyczących wszystkich grup wiekowych mieszkańców, także dzieci. Przyjęcie tej zasady także w Warszawie przez władze samorządowe jest konieczne dla skuteczności procesów naprawczych.

\footnotetext{
${ }^{10}$ Te problemy omówiono m.in. we wspomnianym $5 g$ Space Appeal podpisanym przez 3 tys. lekarzy, którego adresatami są Organizacja Narodów Zjednoczonych, Światowa Organizacja Zdrowia, Unia Europejska i Rada Europy. Zawarto w nim informacje o badaniach naukowych wykazujących szkodliwość przebywania organizmów żywych w środowisku napromieniowanym radiofalowo nawet na poziomie mniejszym niż wytyczony w skali międzynarodowej i krajowej. Nagromadzenie dodatkowo gęsto rozmieszczonych anten zwiększy zdecydowanie to napromieniowanie wielokrotnie. Przytaczano na ten temat ponad 10 tys. recenzowanych badań.

${ }^{11}$ Występujące zaburzenia i choroby w sytuacji napromieniowania: zaburzenia rytmu serca, zmiany w ekspresji genów, zmiany w metaboliźmie, zmiany w rozwoju komórek macierzystych, nowotwory, choroby sercowo-naczyniowe, zaburzenia funkcji poznawczych, uszkodzenia DNA, negatywny wpływ na ogólne samopoczucie, wzrost liczby wolnych rodników, problemy w nauce i zaburzenia pamięci, pogorszenie jakości i ruchliwości plemników, poronienia, uszkodzenia neurologiczne, otyłość i cukrzyca, stres oksydacyjny (Firstenberg, 2019).
} 


\section{"Program ulice bez pyłu”}

Organizacje prospołeczne w Warszawie mając świadomość szkodliwości pyłu i kurzu na ulicach centrum miasta, proponują m.in. wdrożenie programu regularnego mycia ulic na mokro (,program ulice bez pyłu”), stosowanego $\mathrm{w}$ dni o temperaturze powyżej $0^{\circ} \mathrm{C}$.

Podobne praktyki dotyczą także wszelkich powierzchni we wnętrzach urbanistycznych (place, podwórka) i w pomieszczeniach lokali usługowych i innych powszechnie dostępnych. W określonych warunkach klimatycznych nie jest to tylko sprawa estetyki, ale także zdrowia wszystkich użytkowników. Choroby wynikające $\mathrm{z}$ uczulenia na pył, kurz i inne zanieczyszczenia powietrza stają się obecnie normą.

\section{Ściany i chodniki betonowe chłonące zanieczyszczenia}

W niektórych bardziej rozwiniętych technologicznie krajach w narażonej na zanieczyszczenie powietrza (np. pyły, piaski) zabudowie metropolii stosuje się specjalne ściany pochłaniające tego typu zanieczyszczenia.

Jedną z pierwszych eksperymentalnych nawierzchni zastosowanych $\mathrm{w}$ śródmieściu Warszawie jest chodnik z betonu fotokatalitycznego $(350 \mathrm{~m}$ długości) ułożony przy rondzie Daszyńskiego. Ma on zdolność redukcji z powietrza około $30 \%$ tlenków azotu (Newsweek.pl, 2019). W ramach badań laboratoryjnych redukcja dochodziła do 70\% (Miejskie Centrum Kontaktu Warszawa 19115, 2019). Są to pierwsze eksperymentalne badania, nie ma jeszcze konkretnych opracowań naukowych.

W Polsce należy rozwinąć badania naukowe zmierzające do osiągnięcia możliwości produkcji takich ścian, chodników i innych elementów wyposażenia przestrzeni publicznych $\mathrm{w}$ mieście, które likwidują zanieczyszczenia $\mathrm{w}$ powietrzu $\mathrm{w}$ ich otoczeniu. Wraz $\mathrm{z}$ innymi metodami stosowanie takich materiałów będzie wspomagać walkę z niedogodnościami zmian klimatycznych.

Rys. 2. Model Wiednia według Theodora Fritscha z 1896 roku ( $\mathrm{z}$ archiwum autorki)

Fig. 2. Model of Vienna by Theodor Fritsch from 1896 (from the author's archive)

\section{Rola „klinów nawietrzających" w budowaniu prozdrowotnej struktury miasta. Sieciowy układ zieleni}

Podczas kiedy Warszawa uwalniała się spod zaboru rosyjskiego w 1916 roku, wdrażano w życie pierwszy plan regulacyjny miasta po wcześniejszych planach parcelacji. Był on bardzo postępowy - przede wszystkim ujęto w nim miasto jako całość wraz z propozycją jego struktury. Przełom wieków XIX i XX to czas nowych wizji struktury miast, utopii o geometrycznych kształtach, jak model Fritscha Wiednia z 1896 roku o koncentrycznym układzie $\mathrm{z}$ radialnie rozmieszczonymi wachlarzowo dzielnicami mieszkaniowymi oraz terenami zieleni w formie klinów skierowanych od peryferii do centrum i przenikających śródmieście (rys. 2).

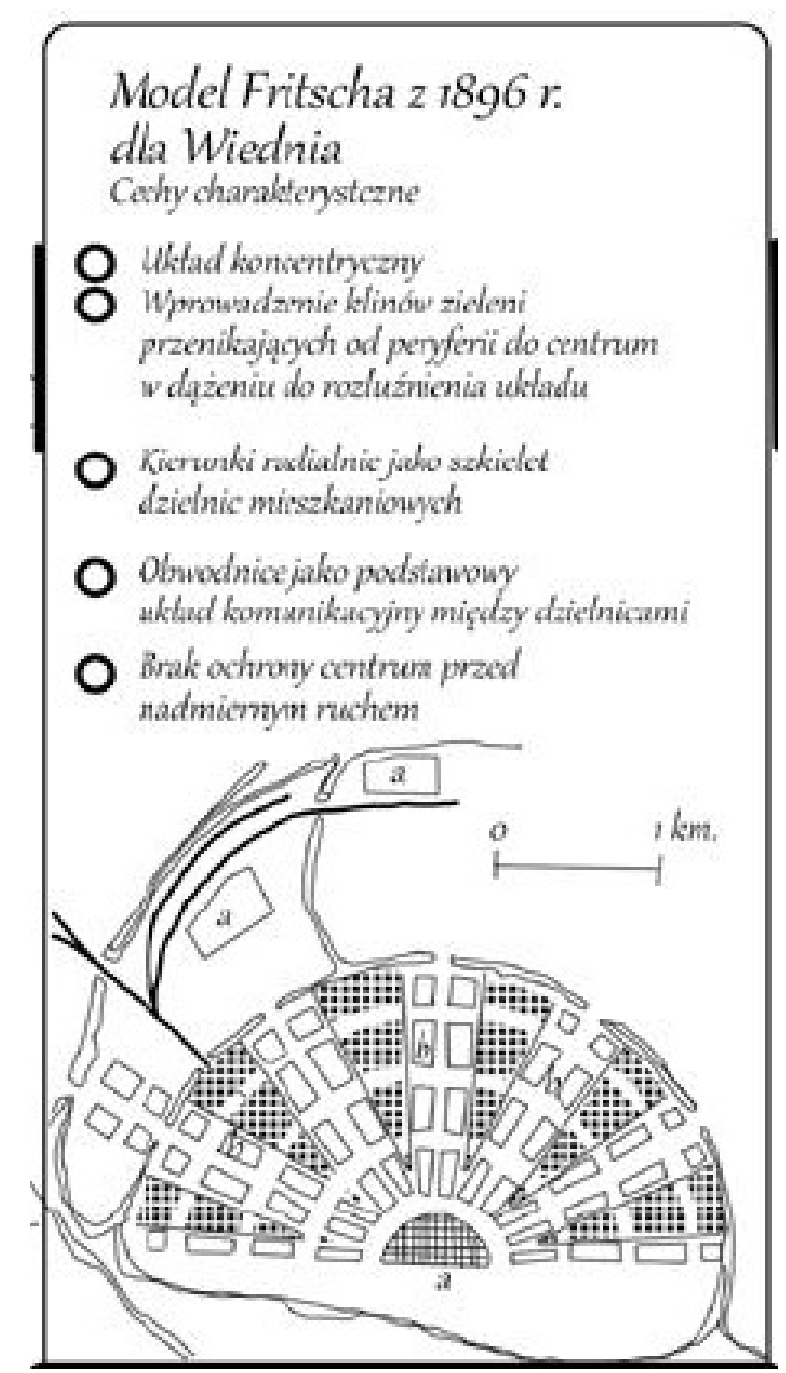




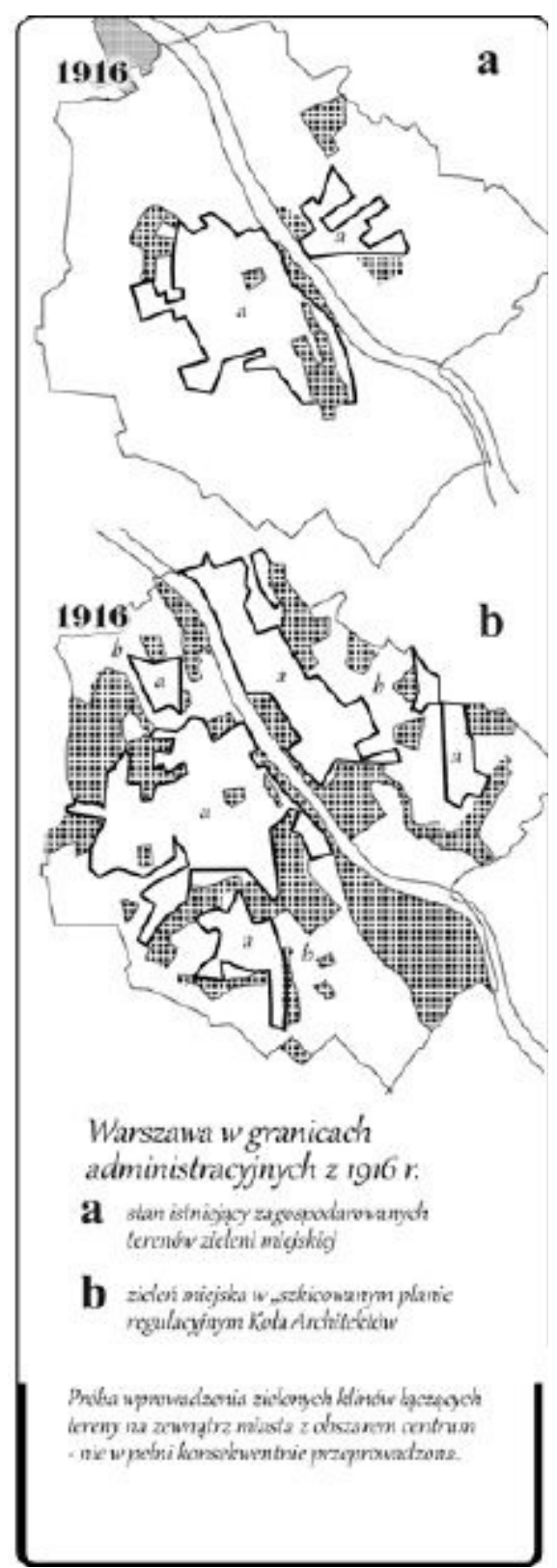

Plan regulacyjny ówczesnej Warszawy to nie tylko idea, ale realistyczna wizja. Na rysunku inwentaryzacji zieleni w granicach Warszawy z 1916 roku (rys. 3a) wyróżnia się „klin nadrzeczny” i incydentalne niewielkie parki i cmentarze. Już wówczas w szkicowanym planie regulacyjnym Koła Architektów poszerzano istniejące enklawy zieleni, dążąc do utworzenia ciągów wiążących otwarte tereny pozamiejskie
Rys. 3. Zieleń w Warszawie w 1916 roku: a - istniejące obszary zieleni miejskiej; b - propozycja poprawy systemu terenów zieleni miejskiej przygotowana przez Koło Architektów

Fig. 3. Warsaw greenery in 1916: a - existing urban green areas; $b$ - proposition for shaping of the greenery system by architectural association the Koło Architektów

z sekwencjami kolejnych skwerów i parków w środku miasta (rys. 3b).

Pierwszym klarownym modelem dla Warszawy był planowany system terenów zieleni w śródmieściu z planu regulacyjnego z 1931 roku. Wprowadzono konsekwentnie zasadę zachowania ,zielonych klinów”.

Mając świadomość dominujących wiatrów z kierunku zachodniego, ustalono trzy dosyć szerokie 
korytarze z zielenią od tej strony oraz jeden klin po praskiej stronie, umożliwiający wywiewanie z miasta niekorzystnych zanieczyszczeń w powietrzu (rys. 4). Wzmocniono także klin centralnie przebiegający przez miasto po obydwu stronach Wisły (Guranowska-Gruszecka, 2013). W 60 lat później prof. Jan M. Chmielewski badając miasta i gminy o najwyższych wskaźnikach urbanizacji, w Obszarze Metropolitalnym Warszawy wyraźnie wskazał pasmo zachodnie jako najbardziej aktywne pod względem rozwoju (Chmielewski, 1994). Oznacza to, że dominujące wiatry właśnie $\mathrm{z}$ kierunku zachodniego przenosza wszelkie zanieczyszczenia z tych terenów miast, miasteczek i wsi w kierunku centrum Warszawy, generując smog nad stołecznym śródmieściem. W procesie naprawczym istotnym zagadnieniem jest zatem dokładne określenie, z jakich źródeł energii korzystaja mieszkańcy i pracownicy terenów zurbanizowanych pasma zachodniego i w jaki sposób można wymienić te źródła na bardziej ekologiczne.

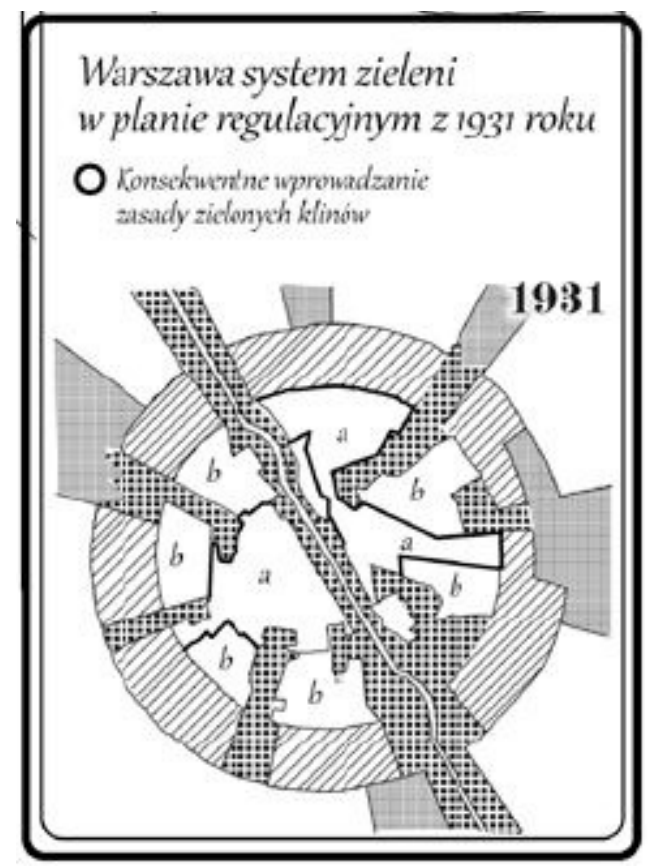

Jednocześnie przy opracowywaniu studium uwarunkowań i kierunków zagospodarowania przestrzennego m.st. Warszawy uchwalonego w 2006 roku lekkomyślnie zrezygnowano $\mathrm{z}$ opisanych tu czytelnych „klinów przewietrzających”, dopuszczając w różnym stopniu ich zabudowanie. Obecnie nawet sposób lokalizowania budynków w poprzek tych klinów i kierunków wiatrów stanowi bariery w przewietrzaniu miasta. Powraca dyskusja na te tematy, już niestety trochę za późno ${ }^{12}$. Tym niemniej po przeprowadzeniu wnikliwej analizy istniejącego stanu zagospodarowania i kierunków nawietrzania należy z pietyzmem powrócić do dawnej koncepcji, ustalić racjonalne możliwości kontynuacji bądź odnowy terenów zieleni, uruchomienia ponownego potencjału zieleni we wszelkich możliwych postaciach jako życiodajnego zaplecza przyrodniczego. Wszelkie pomysły pojawiające się w Zarządzie Zieleni Miejskiej m.st. Warszawy maja racje bytu: dosadzanie roślinności przy ulicach, lasy „deszczowe” na terenach dawnych fortów obronnych,

Rys. 4. System ,zielonych klinów” w śródmieściu Warszawy według planu regulacyjnego z 1931 roku (Guranowska-Gruszecka, 2013)

Fig. 4. The system of "green wedges" in the Warsaw center according to the 1931 regulatory plan (Guranowska-Gruszecka, 2013)

\footnotetext{
${ }^{12}$ W „Gazecie Wyborczej” w 2017 roku ukazał się krytyczny artykuł o działaniach ratusza, który namawia do ochrony „klinów przewietrzających”, a jednocześnie kilkanaście lat temu zbudował szkołę na środku „zielonego klina” (Chełmiński, 2017).
} 
rewitalizacja parków historycznych oraz wzbogacenie o atrakcyjne prozdrowotne elementy parków współczesnych (Pole Mokotowskie), lokowanie zbiorników wodnych $\mathrm{w}$ przestrzeniach publicznych, zamiana betonowych i asfaltowych ścieżek wzdłuż bulwarów wiślanych na gruntowe drogi spacerowe $\mathrm{z}$ nawierzchniami z naturalnych materiałów.

Zgodnie ze współczesnymi teoriami urbanistycznymi rozwoju miast promującymi sieciowe układy różnych elementów struktury miejskiej, w tym także zieleni, dążenia naprawcze zaistniałej sytuacji w Warszawie powinny zmierzać do połączenia istniejących fragmentów ciągów i zespołów zieleni publicznej w spójny system ciągły. Wymaga to zaakceptowania takiej koncepcji jako docelowej i systematycznego uzupełniania brakujących ogniw tego systemu. Sa one stosunkowo niewielkie w porównaniu $\mathrm{z}$ wielkim potencjałem dla utworzenia spójnego systemu sieciowego zieleni w śródmieściu Warszawy. Na rysunku 5 przedstawiono schematyczny projekt sieci terenów zieleni dla stołecznego śródmieścia - propozycja autorki opracowana w 2018 roku.

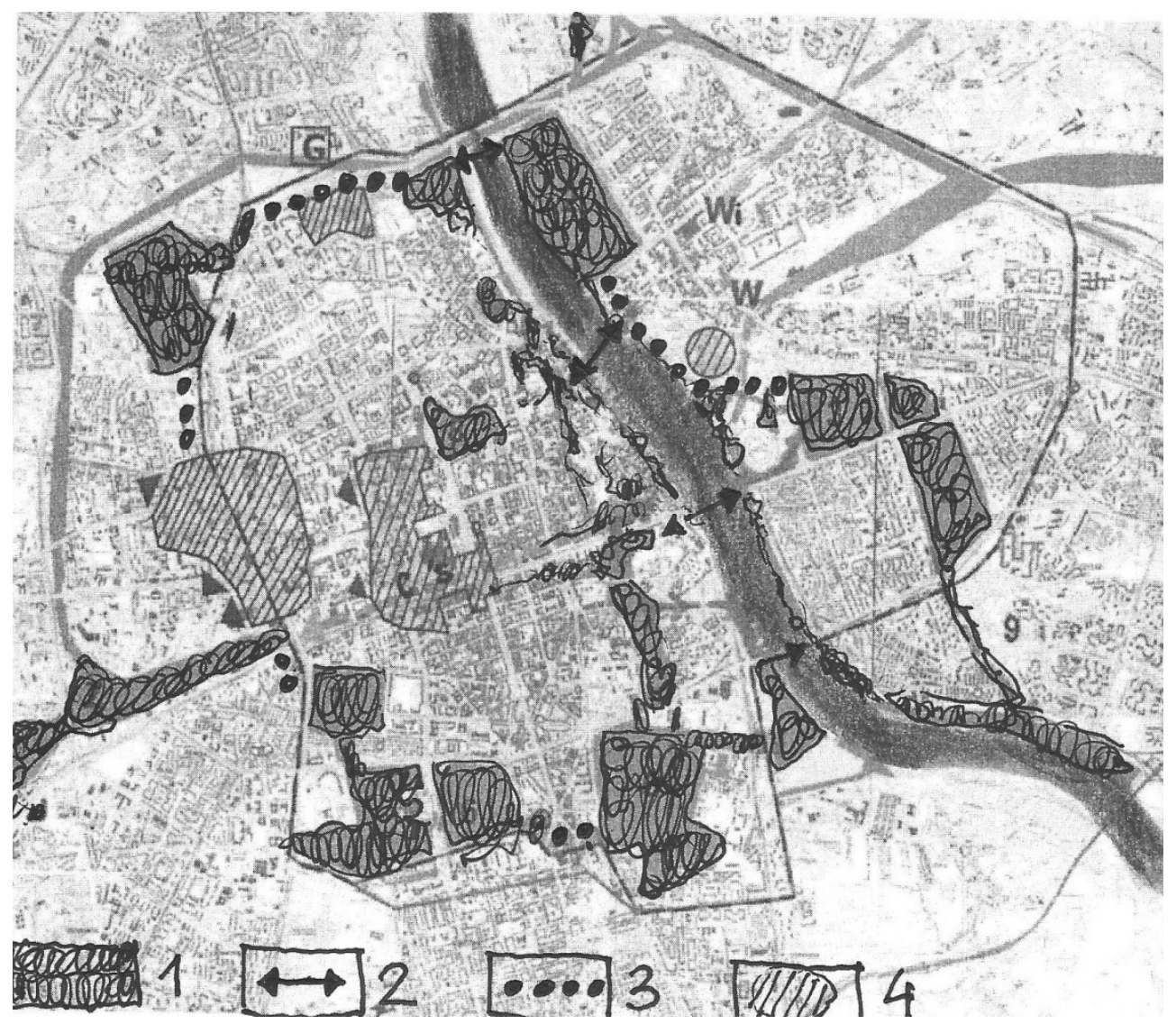

Rys. 5. Koncepcja sieciowego układu zieleni w śródmieściu Warszawy: 1 - tereny zieleni (parki, ogrody zoologiczne, cmentarze, ogródki działkowe); 2 - powiązania pieszo-rowerowe, m.in mosty przez Wisłę; 3 - fragmenty sieci do uzupełnienia poprzez tzw. zielone dachy i zielone ściany; 4 - kształtujące się obszary centrum Warszaw (projekt autorki, 2018)

Fig. 5. Green network layout concept in the downtown of Warsaw: 1 - greenery areas (parks, zoological gardens, cemeteries, allotments); 2 - pedestrian and bicycle connections including bridges over the Vistula; 3 - network fragments to completed by so-called green roofs and green walls; 4 - shaping the area of the centre of Warsaw (design by the author, 2018) 


\section{Warszawa na tle decyzji rewitalizacyjnych w innych miastach}

Począwszy od pierwszych lat XXI wieku porządkowanie śródmieść miast metropolitalnych $\mathrm{w}$ Europie stało się zasadą. Pojawiają się kolejne przykłady miast z aranżacją obszarów centralnych ,przyjaznych” dla ludzi z wyłączeniem ruchu samochodów osobowych. Nawiązując do opisanych badań z 2018 roku Wojewódzkiego Inspektoratu Ochrony Środowiska, likwidacja ruchu kołowego na wybranych fragmentach obszarów śródmiejskich z jednoczesną istotną poprawą sprawności transportu zbiorowego może zlikwidować do około $80 \%$ zanieczyszczeń powietrza $\mathrm{z}$ tych obszarów (pylenie wtórne z jezdni). Wziąwszy pod uwagę, że jest to charakterystyczne dla śródmieścia Warszawy źródło zanieczyszczenia powietrza, proces taki powinien być w stolicy dokonany.

Tymczasem mimo stawianych propozycji władzom wyborczym przez urbanistów niecałe 10 lat temu, aby zacząć proces wyłączania z ruchu lub ograniczania ruchu samochodów osobowych w kolejnych strefach śródmieścia Warszawy, politycy nie przyjęli takiego rozwiązania, dopuszczając bardzo uciążliwe nasycenie ulic śródmiejskich ruchem kołowym powodującym codzienne wielogodzinne postoje zamiast sprawnego poruszania się w tych przestrzeniach (wybory $\mathrm{z}$ lat 2014, 2018).

Skutkiem tych nieodpowiedzialnych działań są następujące zjawiska. W skali Polski przekroczenia dopuszczalnego poziomu zanieczyszczeń powietrza są na ogół niewielkie. W mieście stołecznym, rozwijającym się gwałtownie, wzbogacanym każdego dnia o kolejne miejsca pracy, nowe usługi, biura i inne funkcje przyciągające do Warszawy nowych mieszkańców i pracowników, wzrasta liczba samochodów osobowych przy równoczesnym niewydajnym transporcie publicznym. Przykład jak projektować fragmenty stołecznego śródmieścia, aby tworzyły strukturę „przyjazną” ludziom, przedstawili Mateusz Boguszewski, Weronika Korpalska, Agata Polkowska i Dorota Siczek we wcześniej cytowanej książce Węzly miasta, rozdział Implozja (Boguszewski, Korpalska, Polkowska i Siczek, 2018). Idee implozji w zasadach projektowania $\mathrm{z}$ pewnością są warte spopularyzowania $\mathrm{w}$ odrębnym artykule.

Poszczególne odcinki linii metra realizowane są powolnie wobec konieczności zmagania się z tzw. kurzawką warszawską, trudną do nieustannego pokonywania przy nowych inwestycjach podziemnych, powodującą nierzadko katastrofy budowlane. Sposób projektowania tych linii godzi w racjonalność zamierzeń, co gorsza zrealizowanych ${ }^{13}$. Nie zbudowano doprowadzenia linii metra do Dworca Centralnego PKP. Podobnie nie ma linii metra przy dworcu Śródmieście PKP czy Dworcu Zachodnim PKP i PKS, chociaż inwestorzy zostawili tam możliwość doprowadzenia zamiennie np. tramwaju w przyszłości. Powodem, dla którego stacja Warszawa Śródmieście PKP znalazła się pomiędzy skrzyżowaniami ulic Marszałkowskiej i Emilii Plater z Al. Jerozolimskimi, była intencja umieszczenia tej stacji na osi Pałacu Kultury i Nauki w latach 50. XX wieku. W świetle funkcjonującej od lat 70. XX wieku w krajach Europy Zachodniej polityki organizacji publicznego transportu zbiorowego (sprawdzonej już w teorii węzłów przesiadkowych) projektowanie i budowanie linii transportu miejskiego według kompozycji architektury naziemnej z okresu socrealizmu brzmi jak kiepski żart, nie ma w tym logiki oraz lekceważy to potrzeby użytkowników. Dla ułatwienia przemieszczania się pasażerów swego czasu zamierzano wprowadzić naziemne chodniki ruchome łączące Dworzec Centralny z dworcem Śródmieście, ale nie wykonano tego zamysłu.

Inny przykład to Trakt Królewski stanowiący zabytkową przestrzeń prowadzącą do pomnika UNESCO Starego Miasta, odwiedzaną thumnie w ciepłych

\footnotetext{
${ }^{13} \mathrm{Na}$ początku lat 90. na międzynarodowej konferencji, która odbyła się w Warszawie i dotyczyła nowych inwestycji w rodzącej się metropolii warszawskiej, m.in. prezentowano rozwiązania sieci metra w Ameryce Północnej (USA, Kanada), także w Europie (Francja), gdzie przy niekorzystnych warunkach gruntowych zastosowano wariant kolei naziemnej na wiaduktach. Takie inwestycje obiektywnie są tańsze o około $30 \%$ niż linii podziemnych, w przypadku budowy tuneli w warunkach geotechnicznych z kurzawką nawet kilkakrotnie. Nie wybrano w dalszych pracach sugerowanego wariantu, stąd proces budowy metra stale przerywany katastrofami budowlanymi się przedłuża, opóźniając postęp realizacji (doświadczenia heurystyczne autorki).
} 
porach roku przez turystów z Polski i całego świata. Zamiast obsługi tego historycznego traktu ekologicznymi środkami transportu zbiorowego jeżdżą po nim autobusy z silnikami spalinowymi ponad 20 linii autobusowych, zatruwając powietrze i hałasując na przystankach, tuż obok stolików ustawionych na zewnątrz lokali gastronomicznych. O ekologicznych środkach transportu zbiorowego mówi się nawet w mediach, ale rzeczywistość wraz z obowiązującymi dokumentami prawnymi jak miejscowe plany zagospodarowania przestrzennego $\mathrm{w}$ dalszym ciagu akceptuje opisaną tu sytuację historycznych fragmentów śródmieścia.

\section{Wzorcowe rozwiązania śródmieścia Gandawy - cykle realizacji}

Problemy rozwiązań prozdrowotnych środowiska życia są traktowane w Europie Zachodniej jako najbardziej istotne zagadnienia zmagań kreatorów współczesnych miast, czyli planistów i zarządców. W Gandawie jako jednej z pierwszych miast zaczęto realizować takie przekształcenia. Obecnie jest to wzorzec dla podobnych działań (Prokop i Pawlak, 2018).

W wyniku analizy badań demograficznych ustalono, że współczesne zmiany dotyczą m.in. istotnego wzrostu liczby mieszkańców (przewiduje się do 2050 roku około dwukrotny wzrost mieszkańców w mieście). W śródmieściu oznaczać to będzie zmiany infrastruktury transportowej oraz zmiany kultury przemieszczania się ludzi. Wprowadzono nowy system mobilności dla miasta ${ }^{14}$. Co roku Gandawę odwiedza $3 \mathrm{mln}$ turystów. Na terenach poprzemysłowych i pokolejowych stworzono głównie obiekty terenów zieleni. Dominuje charakterystyczna kultura przemieszczania się na rowerze. Wprawdzie istnieje sieć tramwajowa i liczne linie autobusowe, ale samochód jest jednak podstawowym środkiem lokomocji.

Kilkuetapowa historia przekształceń Gandawy uczy, że wdrożenie nowych rozwiązań może, a nawet czasem musi być dokonywane w kilku fazach, żeby osiągnąc w pełni satysfakcjonujący rezultat. Od lat 70. dążono do odtworzenia zbiegu dwóch rzek, spotykających się w mieście, których koryta na początku XX wieku zostały zasypane, aby stworzyć komunikację drogową. Pierwszy program zrównoważonej mobilności wprowadzono w 1994 roku. Mimo protestów mieszkańców w 1997 roku 35 ha historycznej części miasta wyłączono całkowicie $\mathrm{z}$ ruchu samochodowego.

Kolejny plan tzw. Pegasus w 2003 roku zawierał: koordynacje poprawy transportu publicznego, budowę nowych oraz modernizację istniejących linii autobusowych i tramwajowych. Program rozwoju komunikacji miejskiej okazał się tak dobrze usprawniony, że postanowiono go rozszerzyć na całą Flandrię Zachodnią.

W 2011 roku wprowadzono pierwszą w Belgii drogę typu fietsstraat, głównie dla ruchu rowerowego i z zachowaniem pierwszeństwa tego ruchu. Samochody moga jechać $\mathrm{z}$ maksymalną prędkością $30 \mathrm{~km} \cdot \mathrm{h}^{-1}$ i nie mogą wyprzedzać rowerzystów. W wyniku zastosowania tego systemu spadła o kilkanaście procent liczba przybywających do centrum samochodów. Ze statystyk wiadomo, że dalej rosła liczba samochodów (nowych) w mieście i okolicy, a niektórzy zamiast obwodnicą dostawali się samochodem przez miasto do swoich celów. Postanowiono zmienić zasady.

Nowy plan mobilności drugi etap wprowadzono w 2017 roku. Poprzedzono go starannymi konsultacjami społecznymi i edukacyjnymi, tłumacząc założone cele i zasady korekty rozwiązań. Celem było osiągnięcie bezpieczniejszych ulic i placów oraz wytworzenie atrakcyjnego środowiska miejskiego do życia ludzi, jednocześnie zachowując dostępność (także ekonomiczną) wprowadzanych innowacji. Największe kontrowersje budziło wyłączanie ze środka miasta większego niż dotychczas obszaru z ruchu samochodów osobowych. Wprowadzono dwa programy: Circulation Plan i Parking Plan. Circulation Plan polegał na wyłączeniu ruchu tranzytowego samochodów przez centrum, dopuszczając go tylko po obwodnicy wokół zabytkowej części miasta. Obszar po wewnętrznej stronie obwodnicy podzielono na sześć zasadniczych

\footnotetext{
${ }^{14}$ Gandawa jest trzecim co do wielkości miastem w Belgii, stolicą prowincji Flandrii Zachodniej. Miasto jest bardzo zróżnicowane demograficznie i etnicznie, mieszka w nim około 250 tys. ludzi (ok. 25\% stanowią studenci licznych uniwersytetów). Gandawa jest jednym z miast o największej gęstości zaludnienia w Europie.
} 
sektorów komunikacyjnych o ustalonych ściśle zasadach poruszania się w nich. Granice między sektorami określały albo kanały wodne albo ulice o większych przekrojach i większym natężeniu ruchu. Poruszanie się między sektorami dozwolone było tylko $\mathrm{z}$ wykorzystaniem obwodnicy. Jeżeli granice nie były czytelne, stosowano czerwone pasy albo inną widoczną z daleka sygnalizację. Parking Plan miał zapewnić mieszkańcom centrum parkowanie w pobliżu swoich domów, a gościom na tym terenie pomóc $\mathrm{w}$ znalezieniu miejsca. Zapobiegano dłuższym postojom dzięki wprowadzeniu czterech stref o innych taryfach płatności. W pobliżu węzłów przesiadkowych postój był bezpłatny. W centrum zbudowano parkingi podziemne lub wielopoziomowe. Parkingi w pobliżu strefy historycznej dla pieszych były zdecydowanie droższe niż inne. Ceny rosły też w miare kolejnych godzin postoju, co miało zmuszać klientów do ograniczonego czasu przebywania $\mathrm{w}$ tej strefie.

Specjalna strefa pieszo-rowerowa składała się z pięciu oddzielnych obszarów. Obsługiwały ją trzy elektryczne autobusy oraz tradycyjny miejski transport publiczny. Taksówkom pozwolono na korzystanie $\mathrm{z}$ dróg przeznaczonych dla transportu publicznego. O pozwolenie na przemieszczanie się po tych drogach mogli ubiegać się mieszkańcy, handlarze oraz dostawcy. Zapewniono elektroniczna kontrole dostępu przy wjazdach na teren wyłączony $\mathrm{z}$ ruchu samochodowego.

Dodatkowo w programach tych dopuszczono np. wystąpienia mieszkańców o wyłączenie ich ulic z ruchu, po to żeby dzieci mogły bezpiecznie się bawić. Ustalono też wygodny system pozostawiania rowerów na ulicy z ich rejestracją w razie kradzieży. Kolejne działania to usprawnienia i modernizacja transportu zbiorowego, np. linii tramwajowych. Stosuje się także zasadę współużytkowanych samochodów, co oczywiście ogranicza liczbę samochodów w strefie centralnej. Koniecznością i generalną zasadą było także stałe informowanie społeczeństwa o podejmowanych działaniach oraz partycypacja i edukacja społeczna, co poskutkowało przyzwoleniem społecznym na te przemiany.

Koncepcje przekształceń do 2050 roku miały hasło transportu o zerowej emisji szkodliwych substancji. Wnioski z programów rewitalizacji śródmieścia
Gandawy mogą mieć zastosowanie dla przekształceń centrum Warszawy.

Porównując ten wzorcowy program dla Gandawy z działaniami w Warszawie w strefie śródmiejskiej, należy przede wszystkim zwrócić uwagę na brak umiejętności zarządzania takimi skomplikowanymi przekształceniami w Polsce, a szczególnie w Warszawie, gdzie sprawy te sprawiają najwięcej problemów i zapanowanie nad nimi wydaje się bardzo trudne.

Zarządzanie składa sie z czterech etapów: planowania przekształceń, organizacji (czyli szczegółowego ustalenia realizacji zaplanowanych działań), kontroli, czy zrealizowany system działa zgodnie z określonymi na wstępie celami, naprawy tych elementów, których działanie daje niewłaściwe efekty. Analizując przygotowania w Warszawie do przekształceń obszaru śródmieścia $\mathrm{z}$ uwzględnieniem stref o ograniczonym ruchu samochodowym, trzeba jasno stwierdzić, że nawet nie ma kompleksowego programu w dziedzinie planowania. Jak wyjaśniano to wcześniej, brak jest współpracy międzybranżowej oraz nawet współpracy między zarządcami poszczególnych środków transportu, każdy z nich planuje swoje linie wraz z przystankami całkowicie odrębnie. Tymczasem nie dostrzega się, że mieszkańcy czy pracownicy działający na tym obszarze są najważniejsi i ich potrzeby powinny być zaspokojone. Zanim poszczególni branżyści zaczna planować swoje zadania w obszarze śródmiejskim, należy stworzyć zespół zarządzający, który będzie w stanie sprostać temu skomplikowanemu zadaniu. Sa to struktury mało znane w naszej polskiej rzeczywistości, dlatego warto brać przykład ze sprawdzonych źródeł.

\section{PODSUMOWANIE}

Walka $\mathrm{z}$ warszawskim smogiem $\mathrm{w}$ miejscach jego przyczyn wymaga wielonurtowych działań, równocześnie prowadzenia różnych prac zapobiegawczych opisanych w tym artykule. Tylko sukcesywnie prowadzone zabiegi w opisanych tu dziedzinach mogą stopniowo przynieść pozytywne rezultaty. Obserwując ambitne działania społeczności w krajach Europy Zachodniej doprowadzenia w ciągu najbliższych 30 lat do bezemisyjnych napędów środków transportu miejskiego, należy dołożyć w Polsce starań, aby również 
rozwinąć badania naukowe zmierzające do realizacji takich rozwiązań, ale także zachęcić i wspomóc np. Stowarzyszenie Czysta Polska, dbające wraz z wolontariuszami o Polskę Południową, aby zadbali także o stolicę - Warszawę.

Przedstawione w pracy wnioski i wyniki wielonurtowych rozważań stanowią zaledwie zarys koncepcyjny proponowanych kierunków naprawy sytuacji i wymagają dalszych profesjonalnych działań badawczych.

Należy także rozwinąć system zarządzania związany $\mathrm{z}$ rozpoczynającą się obecnie wielką akcją walki z niepokojącymi skutkami zmian klimatycznych. W przypadku obszarów metropolitalnych są to zadania, które muszą być rozwiązywane mądrze, skutecznie i spójnie jako komplementarna całość zapobiegania niepożądanym zdarzeniom, ujmująca różne dyscypliny nauki.

\section{PIŚMIENNICTWO}

Airly (2019). Smog - definicja i informacje o zjawisku. Pobrano z lokalizacji: https://airly.eu/pl/smog-definicja2019 [dostęp 12.10.2020].

Airly (2020). \#OddychajPolsko 2020. Raport o stanie powietrza $w$ Polsce. Pobrano z lokalizacji: https://airly. org/en/static/AIRLY RAPORT onet 2020-ec24a5b3f0 c49784a24001a3965f7d2a.pdf [dostęp 07.10.2020].

Alexander, Ch. (2008). Język wzorców. Miasta - budynki - konstrukcja. Gdańsk: Gdańskie Wydawnictwo Psychologiczne.

Bhattacharyya, S., Klerks, P. L. i Nyman, J. A. (2003). Toxicity to freshwater organisms from oils and oil spill chemical treatments in laboratory microcosms. Environmental Pollution, 122 (2), 205-215.

Biuro Architektury i Planowania Przestrzennego Urzędu m.st. Warszawy [BAiPP] (2018). Atlas ekofizjograficzny Warszawy. Warszawa. Pobrano z lokalizacji: https:// architektura.um.warszawa.pl/sites/default/files/files/ atlas_ekofizjograficzny.pdf [dostęp 12.10.2020].

Boguszewski, M., Korpalska, W., Polkowska, A. i Siczek, D. (2018). Implozja. W K. Guranowska-Gruszecka, M. Łaskarzewska (red.), Węzty miasta (strony 218-225). Warszawa: Fundacja Wydziału Architektury Politechniki Warszawskiej i Naukowy Klub Architektury.

Chełmiński, J. (2017, 17 luty). Smog w Warszawie. Chrońmy kliny nawietrzajace. To one wentyluja miasto. Gazeta Wyborcza. Pobrano z lokalizacji: https://warszawa.wy- borcza.pl/warszawa/7,54420,21383472,rozdrapywaniezielonych-korytarzy.html [dostęp 12.10.2020].

Chmielewski, J. M. (1994). Studium możliwości rozwoju Obszaru Metropolitalnego Warszawy. Raport końcowy. Warszawa: Zakład Planowania Towarzystwa Urbanistów Polskich.

Dunaj, B. (red.) (2001). Słownik współczesnego języka polskiego. Tom 2. Warszawa: Przegląd Readers Digest.

European Environment Agency [EEA] (2020). Air quality in Europe - 2020 report (EEA Report 09/2020). Pobrano z lokalizacji: https://www.eea.europa.eu/publications/ air-quality-in-europe-2020-report [dostęp 08.10.2020].

Firstenberg, A. (2019). International Appeal - stop $5 G$ on Earth and in Space. Referat na konferencji naukowej „Gospodarka przestrzenna, stan obecny i wyzwania przyszłości-ujęcie interdyscyplinarne”, 25-26.09.2017, Wrocław.

Guranowska-Gruszecka, K. (2013). Śródmieście Warszawy wXX wieku. Warszawa: Wydawnictwo WS im. Bohdana Jańskiego.

MacGregor, J. T., Casciano, D. i Müller, L. (2000). Strategies and testing methods for identifying mutagenic risks. Mutation Research, 455 (1-2), 3-20.

Miejskie Centrum Kontaktu Warszawa 19115 (2019). Chodniki antysmogowe. Pobrano z lokalizacji: https:// warszawa19115.pl/-/chodniki-antysmogowe [dostęp 12.10.2020].

Motofaktor.pl (2017). Zasada działania silnika wysokoprężnego. Pobrano z lokalizacji: https://www.motofaktor. $\mathrm{pl} /$ zasada-dzialania-silnika-wysokopreznego [dostęp 07.10.2020].

Najwyższa Izba Kontroli [NIK] (2000). NIK o smogu alarmowata od 2000 roku. Pobrano z lokalizacji: https:// www.nik.gov.pl/aktualnosci/nik-o-smogu-alarmowalod-2000-roku.html [dostęp 12.10.2020].

Najwyższa Izba Kontroli [NIK] (2016). Eliminacja niskiej emisji z kotlowni przydomowych $i$ gminnych $w$ województwie ślaskim. Informacja o wynikach kontroli. (191/2016/P/16/065/LKA). Katowice: Delegatura NIK w Katowicach.

Najwyższa Izba Kontroli [NIK] (2020). O ograniczaniu niskiej emisji.

Newsweek.pl (2019, 31 stycznia). W Warszawie powstat chodnik, który ,zjada” smog. Pobrano z lokalizacji: https://www.newsweek.pl/wiedza/w-warszawie-powstal-chodnik-ktory-zjada-smog/2gsbfb5 [dostęp 28.09.2020].

Pecenik, P. (2009). Wspólne przestrzenie transportowe w miastach na przykładzie Saint Germain-en-Laye, 
Reims i Strasbourg. Zeszyty Naukowe Uczelni Vistula, $66(3), 51-62$.

Pecenik, P. (2017). Obstuga transportowa śródmieścia funkcjonalnego Warszawy w latach 1960-2015 na tle rozwiazań $w$ innych miastach europejskich. Warszawa: Oficyna Wydawnicza Politechniki Warszawskiej.

Prokop, A. i Pawlak, I. (2018). Nowy plan mobilności w Gandawie - rozwiazania i możliwości. W K. Guranowska-Gruszecka, M. Łaskarzewska (red.), Wezzly miasta (strony 130-143). Warszawa: Fundacja Wydziału Architektury Politechniki Warszawskiej i Naukowy Klub Architektury.
Starzyk, A. (2018). Sensualna percepcja miejskości. W K. Guranowska-Gruszecka, M. Łaskarzewska (red.), Węzty miasta (strony 144-155). Warszawa: Fundacja Wydziału Architektury Politechniki Warszawskiej i Naukowy Klub Architektury.

Traczewskiej, T. M. (2011). Biologiczne metody oceny skażenia środowiska. Wrocław: Oficyna Wydawnicza Politechniki Wrocławskiej.

Wojewódzki Inspektorat Ochrony Środowiska w Warszawie [WIOŚ] (2019). Roczna ocena jakości powietrza w województwie mazowieckim. Raport wojewódzki za rok 2019. Warszawa.

\title{
SOURCES OF WARSAW SMOG AND DIRECTIONS OF REMEDYING THIS SITUATION IN THE PLACE OF ITS CAUSES
}

\begin{abstract}
The aim of the article is to present the sources of smog in the capital city of Warsaw based on available research of sanitary institutions from recent years and original observations of phenomena. They led to the conclusion that in addition to chemical air pollution, the city's urban planning has a significant impact, including buildings against green systems, public and individual transport by private cars, and the technical infrastructure used in buildings, as well as the application of management principles in investment activities on a larger scale which in Poland is overlooked. Apart from the analysis of contemporary source materials concerning smog as an unnatural phenomenon of the coexistence of chemical compounds and harmful dusts in the atmosphere, the directions of the situation are presented. Solutions from other European cities (e.g. Ghent) were cited. Therefore, comparative methods of Warsaw with model examples were used, introducing case study methods, presenting examples that successfully protected the urban environment. In the application part, the multi-directional directions of remedial actions are highlighted, as well as the need to apply management principles in the environmental protection actions of Warsaw, important for the achievement of the assumed goals, and not those applicable.
\end{abstract}

Key words: smog, climate change, home furnaces, $5 \mathrm{G}$ radiofrequency radiation, walls and pavements that absorb pollutants, striving for zero emissions, rules of the transport network in the city center 